\title{
ОСОБЕННОСТИ СТРОЕНИЯ И ПЕРСПЕКТИВЫ НЕФТЕГАЗОНОСНОСТИ БОРТОВОЙ ЗОНЫ ПРИКАСПИЙСКОЙ СИНЕКЛИЗЫ
}

Бахитова Г.Ш.

(МГУ им. М. В. Ломоносова)

\section{Резюме содержания:}

Погодаево - Остафьевский прогиб расположен в бортовой зоне Прикаспийской синеклизы. Он представляет собой некомпенсированную впадину позднедевонско - турнейского возраста, наследующую древний Перелюбский прогиб фундамента. Впадина заполнена мощной (400 м) терригенной толщей визейского возраста (косьвинско - радаевские отложения). Бортовые зоны прогиба сложены регрессивно смешенными относителњно друг друга верхнедевонско - турнейскими барьерными рифами.

На территории Погодаево - Остафьевского прогиба месторождения не открыты, но получены притоки на близлежащих площадях из аналогичных отложений. Перспективы нефтегазоносности прогиба связаны с тремя комплексами: верхнедевонско - турнейским, косьвинско - радаевским и, возможно, бобриковским. Открытие месторождений нефти и газа в бортовой зоне прогиба связано с рифовыми постройками верхнедевонско - турнейского возраста. Также перспективы территории следует связывать с зонами выклиниваний на бортах впадины визейской (косьвинско - радаевской) толщи компенсации. Эти отложения могут быть перспективны и во внутренней зоне прогиба, где их мощность увеличена. Отложения бобриковского возраста предположительно нефтегазоносны (по аналогии с Муханово - Ероховским прогибом, где нефтегазоносны песчаные пласты бобриковского возраста) и представлены структурами облекания над барьерными рифами.

В настоящий момент по сейсмическим данным выделены объекты на Западно - Овчинниковской, Овчинниковской, Лебедевской, Малозайкинской, Новотрудовой, Северно - Таловой, Таловой, Южно - Таловой площадях. Это тела небольшого размера, расположенные в зоне барьерно - рифовых уступов.

Изучение осадочной толши бортовой зоны Прикаспийской синеклизы важно для выявления перспектив нефтегазоносности глубокопогруженных горизонтов внутренней части синеклизы.

\section{Тезисы:}

Рассматриваемая территория - северная бортовая зона Прикаспийской синеклизы, в зоне ее сочленения с Волго - Уральской антеклизой. В административном плане - это южные районы Оренбургской области, территория Саратовской области (Саратовское Заволжье), Уральская область Казахстана.

Главный структурный элемент района - основной бортовой уступ Прикаспийской впадины, четко прослеживаемый по поверхности подсолевых отложений палгеовоя.

Главной особенностью территории являются разновозрастные барьерно - рифовые уступы Прикаспийской впадины, смещенные в плане относительно друг друга. По материалам бурения и сейсморазведки выделено четыре бортовых уступа: эй- фельский, фаменско - турнейский, визейско - башкирский, московско - артинский. Бассейновые склоны этих барьеров образуют крутые уступы, сформированные седиментационными процессами, связанными с рифообразованием и некомпенсированным осадками пригибанием Прикаспийской впадины в докунгурское время.

Верхнедевонско-турнейский барьерно-рифовый уступ формирует борта Погодаево - Остафьевской некомпенсированной палеовпадины, наследующей (дорифейский) Перелюбский прогиб фундамента. Прогиб располагается на обрамлении Прикаспийской синеклизы, представляя собой далеко вдающийся в область палеошельфа глубоководный ее залив, сформированный в фаменско - турнейское время и компенсированной мощной терригенной толщей нижнего карбона. Прогиб находится на территории Южно - Бузулукской нефтегазоносной провинции и оценивается в качестве нефтегазоперспективного объекта.

Большинством исследователей прогиб рассматривается в качестве аналога Мухано - Ероховского прогиба, рифовые борта которого контролируют подавляющую пасть нефтяных залежей Оренбургской области (около 50 процентов). Барьерные рифы Погодаево - Остафьевской палеодепрессии, по аналогии с Мухано - Ероховским прогибом, регрессивно смещены в плане относительно друг друга. По всей вероятности, они образуют довольно ттирокий пояс развития рифогентьх пород.

Северный и северо - восточньй борта Погодаево - Остафьевского прогиба весьма перспективны для поиска новьх месторождений. Основные перспективы связаны с барьерно - рифовыми зонами в фаменско - турнейском комплексе отложений и локальными постройками во внутренней части депрессии. В настоящий момент по сейсмическим данным выделены тела небольшого размера на площадях, расположенные в зоне барьерно - рифовых уступов. Также перспективы территории следует связывать с зонами выклиниваний на бортах впадины косьвинско - радаевской толщи компенсации. Эти отложения могут быть перспективны и во внутренней зоне Погодаево - Остафьевского прогиба, где их мощность увеличена до нескольких сот метров. Перспективность этих отложений подтверждена притоком нефти в скв. 556 Миропкинской.

Отложения бобриковского возраста предположительно нефтегазоносны (по аналогии с Муханово - Ероховским прогибом, где нефтегазоносны песчаные пласты бобриковского возраста) и представлены структурами облекания над барьерными рифами. 